\title{
Performance of Holstein and Swedish-Red $\times$ Jersey/Holstein crossbred dairy cows within low- and medium-concentrate grassland-based systems
}

\author{
C. P. Ferris, ${ }^{* 1}$ P. J. Purcell, ${ }^{*}$ A. W. Gordon, $†$ T. Larsen, $\ddagger$ and M. Vestergaard \\ *Agri-Food and Biosciences Institute, Large Park, Hillsborough, Co. Down, BT26 6DR, United Kingdom \\ †Agri-Food and Biosciences Institute, Newforge Lane, Belfast, Co. Antrim, BT9 5PX, United Kingdom \\ łDepartment of Animal Science, Aarhus University, Blichers Alle 20, PO Box 50, DK-8830, Denmark
}

\section{ABSTRACT}

This $2 \times 2$ factorial design experiment was conducted to compare the performance of spring-calving Holstein dairy cows (HOL, $\mathrm{n}=34)$ with Swedish Red $\times$ Jersey/ Holstein crossbred $(\mathrm{SR} \times \mathrm{J} / \mathrm{HOL}, \mathrm{n}=34)$ dairy cows within low and medium concentrate input grasslandbased dairy systems. The experiment commenced when cows calved and encompassed 1 full lactation. Cows were offered diets containing grass silage and concentrates [70:30 dry matter (DM) ratio, and 40:60 DM ratio, for low and medium, respectively] until turnout, grazed grass plus either 1.0 or $4.0 \mathrm{~kg}$ of concentrate/d during the grazing period (low and medium, respectively), and grass silage and concentrates (85:15 DM ratio, and 70:30 DM ratio, for low and medium, respectively) from rehousing and until drying off. No significant genotype $\times$ system interactions were present for any of the feed intake or full-lactation milk production data examined. Full-lactation concentrate DM intakes were 769 and $1,902 \mathrm{~kg} / \mathrm{cow}$ for the low and medium systems, respectively, whereas HOL cows had a higher total DM intake than $\mathrm{SR} \times \mathrm{J} / \mathrm{HOL}$ cows in early lactation, but not in late lactation. Although HOL cows had a higher lactation milk yield than $\mathrm{SR} \times \mathrm{J} / \mathrm{HOL}$ cows, the latter produced milk with a higher fat and protein content, and thus fat plus protein yield was unaffected by genotype. Milk produced by the $\mathrm{SR} \times \mathrm{J} / \mathrm{HOL}$ cows had a higher degree of saturation of fatty acids than milk produced by the HOL cows, and the somatic cell score of milk produced by the former was also higher. Throughout the lactation, HOL cows were on average $30 \mathrm{~kg}$ heavier than $\mathrm{SR} \times \mathrm{J} / \mathrm{HOL}$ cows, whereas the SR $\times \mathrm{J} / \mathrm{HOL}$ cows had a higher body condition score than the HOL cows. Holstein cows had a higher incidence of mastitis and ovarian dysfunction that $\mathrm{SR} \times \mathrm{J} / \mathrm{HOL}$ cows.

Received November 7, 2017.

Accepted March 18, 2018.

${ }^{1}$ Corresponding author: conrad.ferris@afbini.gov.uk
Key words: three-breed crossbreeding, Holstein, Swedish Red, concentrate level, milk yield

\section{INTRODUCTION}

Whereas historic selection programs within the Holstein breed focused primarily on milk production at the expense of health and fertility, selection programs in most countries now include functional traits (Miglior et al., 2005). However, problems within the Holstein breed will take time to reverse, and this is one of several reasons for a renewed interest in crossbreeding.

Benefits of crossbreeding arise through the introduction of desirable traits from a second breed, from hybrid vigor, and through opportunities to minimize the risk of inbreeding. Many breeds have been evaluated within crossbreeding studies, including Normande (Heins et al., 2012), Montbéliarde (Heins et al., 2012; Hazel et al., 2014), Brown Swiss (Dechow et al., 2007; Blottner et al., 2011), Norwegian Red (Begley et al., 2009), and Swedish Red (Piccardi et al., 2014; Malchiodi et al., 2014). However, the Jersey is perhaps the breed most commonly used, with research having demonstrated that Jersey $\times$ Holstein crossbred cows have similar intakes (Heins et al., 2008a; Prendiville et al., 2009; Vance et al., 2012a) and yields of milk solids as Holstein cows (Vance et al., 2012a, 2013), while also having improved fertility (Heins et al., 2008b).

Although the benefits of crossbreeding are now well established, farmers who adopt crossbreeding are faced with an important question, namely which sire breed to use when breeding the $\mathrm{F}_{1}$ crossbred cow. Several breeding strategies exist, including crossing back to one of the parent breeds, using progeny-tested crossbred sires, or using a third breed in a 3-breed rotational crossbreeding program. One of the benefits of the latter approach is the potential to maintain heterosis at an average of $86 \%$ of that found with the $\mathrm{F}_{1}$ cross, compared with an average of only $67 \%$ if maintaining a 2-breed cross (Sørensen et al., 2008). However, as noted by McAllister (2002), although the theoretical advantages of a 3 -breed rotational crossing system are clear, data to 
recommend the third breed, and the use of this approach in practice, are limited. Only a few studies have examined the performance of 3-breed crossbred cows, with these including studies by Malchiodi et al. (2014) involving Montbéliarde $\times$ Swedish Red/Holstein cows, and Hazel et al. (2013, 2014) involving Montbéliarde $\times$ Jersey/Holstein cows.

To help address this issue, the performance of Holstein (HOL) and 3-breed crossbred cows (Swedish Red $\times$ Jersey/Holstein; SR $\times$ J/HOL) cows were compared over a single lactation. The use of the Swedish Red as the third breed within this crossbreeding program was based on several factors, including sire selection programs in Sweden having incorporated fertility and health traits for several decades (Heringstad et al., 2000; Philipsson and Lindhe, 2003). In addition, when used as a first-cross within crossbreeding programs, Scandinavian Red crossbred cows had fewer calving difficulties and still births (Heins et al., 2006a), improved fertility (Heins and Hansen, 2012; Malchiodi et al., 2014; Piccardi et al., 2014), similar lactation fat plus protein yields (Heins et al., 2006b), but higher lifetime yields and greater survival (Heins et al., 2012) compared with purebred Holstein cows. Although crossbred cows, and especially Jersey crossbred cows, are often perceived to be primarily suited to lower concentrate input systems, a recent study (Vance et al., 2013) compared the performance of Holstein and Jersey $\times$ Holstein cows within 3 grassland-based systems of milk production (concentrate inputs of approximately $0.5,1.1$ and 1.7 $\mathrm{t} /$ cow per lactation). This study provided no evidence of a genotype $\times$ nutrition interaction for any of the parameters examined. As crossbred cows are increasingly being used within medium concentrate input systems, the current study was conducted to compare the performance of HOL and $\mathrm{SR} \times \mathrm{J} / \mathrm{HOL}$ cows within both a low and medium concentrate system.

\section{MATERIALS AND METHODS}

This study was conducted at the Agri-Food and Biosciences Institute (AFBI), Hillsborough, Northern Ireland, between January 2013 and February 2014. Four treatments were examined in a continuous 2 (cow genotype) $\times 2$ (system) factorial design experiment. The experiment commenced when the cows calved and was conducted over one full lactation. All experimental procedures in this study were conducted under experimental license granted by the Department of Health, Social Services and Public Safety for Northern Ireland in accordance with the United Kingdom (UK) Animals (Scientific Procedures) Act 1986.

\section{Animals}

The experiment involved 68 spring calving dairy cows, 34 HOL cows and 34 three-breed crossbred cows $(\mathrm{SR} \times \mathrm{J} / \mathrm{HOL})$. The HOL cows had a mean predicted transmitting ability for fat + protein yield of +12 $( \pm 10.6 ; \pm \mathrm{SD}) \mathrm{kg}$ and a mean profitable lifetime index $(\mathbf{P L I})$ of $+£ 141( \pm 123.6 ; \pm \mathrm{SD})$, with these cows being within the top $5 \%$ of Holstein cows in the UK for these 2 parameters. The genetic parameters presented above were determined within the April 2015 proof run. The HOL cows used in the experiment were sired by a total of 11 Holstein-Friesian sires, with these sires selected from within the 20 highest ranking sires for PLI available within the UK during the years that the dams of the HOL cows were bred. The SR $\times \mathrm{J} /$ HOL cows were the offspring of a breeding program in which randomly selected Holstein cows from the AFBI Hillsborough herd were bred to Jersey sires of Danish and New Zealand origin (described previously by Vance et al., 2012a, 2013), with the offspring of this breeding program subsequently bred to sires $(n=6)$ of the Swedish Red breed. These sires were within the 5 highest ranking Swedish Red sires for total merit index available within the UK during the years that the dams of the $\mathrm{SR} \times \mathrm{J} / \mathrm{HOL}$ cows were bred. All cows on the study were multiparous, with the HOL and $\mathrm{SR} \times \mathrm{J} /$ HOL cows having a mean lactation numbers of 2.8 and 2.9 , respectively.

\section{Systems}

Cows from each genotype were allocated to 1 of 2 grassland-based milk production systems (low and medium) within $36 \mathrm{~h}$ of calving, with systems differing in concentrate inputs. Within each genotype cows were balanced across the low and medium systems according to calving date, parity, precalving $\mathrm{BW}$ and BCS, sire, and in the case of HOL cows, predicted transmitting ability for fat + protein yield and PLI. Full details of each of the 2 systems are described below. Cows had a mean calving date of February $15( \pm 26.8 \mathrm{~d} ; \pm \mathrm{SD})$.

Winter Period. During the dry period before the start of the experiment all cows were offered grass silage plus $100 \mathrm{~g} /$ cow per d (target intake) of a dry cow mineral/vitamin mix. Following calving (within 36 h) cows were moved from a maternity pen to freestall cubicle accommodation. Cubicles were fitted with rubber mats that were cleaned daily, bedded with sawdust thrice weekly, and treated with lime weekly. Concrete passageways within the house were cleaned every 2 to 3 $\mathrm{h}$ throughout the day using an automatic slurry scraper system. 
Cows on both systems were offered a mixed diet containing grass silage (produced from a predominantly perennial ryegrass (Lolium perenne) based sward: harvest dates, May 21-23) and concentrates. With the low system, the grass silage and concentrates were mixed in a 70:30 ratio (DM basis), whereas with the medium system the grass silage and concentrates were mixed in a 40:60 ratio (DM basis). The ingredient composition of the concentrate offered $(\mathrm{kg} / \mathrm{t}$, air-dry basis) during the winter period was as follows: barley, 250; maize meal, 250; soybean hulls, 100; soybean meal, 165; rapeseed meal, 165; Megalac, 15 (Volac Ltd., Orwell, Herefordshire, UK); Molaferm, 30 (United Molasses, Belfast, UK); minerals and vitamins, 25.

Diets were prepared using a complete diet mixer wagon (Redrock Varicut, Redrock, County Armagh, Northern Ireland). To ensure consistency in the quality of silage offered with both the low and medium systems, sufficient silage for both systems was initially mixed in the mixer wagon for approximately $5 \mathrm{~min}$, and part of the mix deposited on a clean silo floor. The silage remaining in the wagon was used in the preparation of the low system ration. The silage deposited on the clean silo floor was then placed back in the wagon and used in the preparation of the medium system ration. The order of preparing the rations for each system was changed on alternative days. With each system silage and concentrates were mixed in the wagon for approximately $5 \mathrm{~min}$.

Following mixing, rations for each system were transferred directly from the mixer wagon to feed-boxes mounted on weigh cells, access to which was controlled by a Calan Gate feeding system (American Calan Inc., Northwood, NH) linked to an electronic identification system, thus enabling individual cow intakes to be recorded daily. Uneaten food was removed daily at approximately $0830 \mathrm{~h}$, while the fresh food (mixed rations) was offered ad libitum between 0930 and $1000 \mathrm{~h}$. In addition, all cows were offered $1.0 \mathrm{~kg}$ of concentrate daily via in-parlor feeders, $0.5 \mathrm{~kg}$ at each milking.

Grazing Period. Cows on both the low and medium systems commenced grazing on the April 18, the late turnout date a consequence of a very cold spring during 2013, which severely hampered grass growth. At turnout cows were given access to grazing from approximately $0800 \mathrm{~h}$ until $1430 \mathrm{~h}$ each day. This continued until May 16 when cows commenced full-time grazing. Partway through this transitional grazing period (May 3 ), the concentrate:forage ratios (DM basis) in the diets offered during the confinement part of the day were reduced to 20:80 and 40:60 for the low and medium systems, respectively, whereas the $1.0 \mathrm{~kg} / \mathrm{cow}$ per $\mathrm{d}$ of winter concentrate offered in the milking parlor was replaced by $3.0 \mathrm{~kg} /$ cow per d of a grazing concentrate,
$1.5 \mathrm{~kg}$ at each milking. Fulltime turnout (day and night grazing) occurred on May 16, at which stage the confinement diet was withdrawn, and the level of grazing concentrate offered changed to 3.0 and $6.0 \mathrm{~kg} /$ cow per $\mathrm{d}$ (low and medium, respectively), with these levels subsequently reduced to 1.0 and $4.0 \mathrm{~kg} /$ cow per d (low and medium, respectively) on June 3 . These concentrate levels were maintained until September 17, when they were increased to 2.0 and $5.0 \mathrm{~kg} /$ cow per d (low and medium, respectively), remaining at these levels until rehousing. From October 3 until October 20 the period of grazing was reduced to the interval between am and pm milking, with cows rehoused on October 21. The ingredient composition of the grazing concentrate offered (kg/t, air-dry basis) was as follows: maize, 200; soybean hulls, 200; wheat, 135; soybean, 130; rapeseed extract, 112; Molaferm, 90; maize gluten, 70; Megalac, 20; fine limestone, 10.5; salt and mineral supplements, 25; palm fatty-acid distillate blend, 7.5.

Throughout the grazing season a rotational paddock grazing system was adopted. Holstein and SR $\times \mathrm{J} /$ HOL cows on the low system grazed in a single group, whereas HOL and $\mathrm{SR} \times \mathrm{J} / \mathrm{HOL}$ cows on the medium system grazed in a separate group, with paddocks for each of the low and medium systems arranged sideby-side across the grazing area. The core grazing area consisted of 21 one-day paddocks ( 0.3 ha each) for each system, with additional grazing paddocks introduced into the rotation as the season progressed, or in response to herbage shortages. Paddocks that were not grazed during a rotation (due to excess grass being available, as determined by a grass wedge grassland management tool) were either grazed by a group of nonexperimental cows, or cut and baled for silage. A total of 8 grazing cycles were completed during the grazing season (mean duration, $22.6 \mathrm{~d}$ ). The mean grazing season stocking rate for both the low and medium systems was 4.8 cows/ha.

Throughout the grazing season pre- and postgrazing sward heights were measured daily within the grazing area for each system (40 measurements in a "W" formation) using a rising plate meter (Jenquip, Feilding, New Zealand). During the course of the grazing season, mean pre- and postgrazing sward heights were 10.0 (SD 2.27) and 5.9 (SD 1.21) cm, respectively, for low, and 10.4 (SD 2.0) and 6.1 (SD 1.21) cm, respectively, for medium. Over the entire grazing season the total fertilizer $\mathrm{N}$ application rate on the core grazing paddocks was $233 \mathrm{~kg}$ of $\mathrm{N} / \mathrm{ha}$. The entire grazing area was trimmed (topped) to approximately $50 \mathrm{~mm}$ midway through the grazing season.

Late Lactation Period. Full-time rehousing took place on October 21. After rehousing, cows were offered a mixed diet comprising grass silage (mostly secondary 
re-growth) and winter concentrate (mixed in a 85:15 $\mathrm{DM}$ ratio and a 70:30 DM ratio, for low and medium, respectively). In addition, all cows were offered an additional $1.0 \mathrm{~kg}$ of winter concentrate/cow per d, $0.5 \mathrm{~kg} /$ cow at each milking. Cows remained on these latter diets until they were dried off.

Holstein-Friesian and SR $\times \mathrm{J} / \mathrm{HOL}$ cows completed a mean of $288( \pm 26.1 ; \pm \mathrm{SD})$ and $290( \pm 26.0) \mathrm{d}$ on the experiment, respectively, whereas the respective ranges were 248 to $342 \mathrm{~d}$ and 238 to $345 \mathrm{~d}$.

\section{Breeding and Dry Period Management}

Breeding commenced on April 1 and finished on July 8 (14 wk), with all cows having a minimum period before breeding of $42 \mathrm{~d}$. Cows of both genotypes were bred using AI to 1 of 4 Holstein sires, with these sires selected from within the 20 highest ranking sires for PLI available within the UK that year. Pregnancy was confirmed via rectal scanning at d 60 postinsemination. Cows with a BCS of $\geq 2.5$ were dried off either 8 wk precalving, or if average weekly milk yields fell below $5.0 \mathrm{~kg} / \mathrm{d}$, whereas cows with a BCS of 2.25 or $\leq 2.0$ were dried off at either 10 or 12 wk precalving, respectively. After being dried off, cows were removed from the experiment. Cows within each concentrate input system that were not pregnant remained on their system (low or medium) for the same mean number of days as pregnant cows within that system, after which they were removed from the experiment. All individual cow health disorders and treatments were recorded daily throughout the study by trained stock persons. An incidence of mastitis or lameness was defined as one that required treatment with antibiotics. Ovarian dysfunction was defined as any issue, diagnosed by a veterinary surgeon, that required treatment with either progesterone, prostaglandin, or GnRH-based preparations.

\section{Measurements}

Cows were milked twice daily, between 0600 and 0800 $\mathrm{h}$, and between 1500 and $1700 \mathrm{~h}$, with milk yields recorded automatically at each milking. Milk fat, protein, and lactose concentrations were determined weekly on 2 consecutive (am and pm) milk samples (Milkoscan, model FT 120, Foss UK Ltd., Warrington, UK), whereas milk SCC was determined monthly using a Fossomatic 360 (Foss Electric, Hillerød, Denmark). In addition, on d 5, $15( \pm 1 \mathrm{~d} ; \pm \mathrm{SD}), 29$ and $43( \pm 3 \mathrm{~d})$ postcalving (designated as wk 1, 2, 4, and 6), a sample of milk produced during each of the am and pm milkings was collected, bulked in proportion to yield, and stored at $-20^{\circ} \mathrm{C}$. These samples were subsequently analyzed for a range of metabolites and mastitis indicators, namely glucose and glucose-6-phosphate (Larsen, 2015), BHB (Larsen and Nielsen, 2005), isocitrate (Larsen, 2014), $N$-acetyl- $\beta$-D-glucosaminidase (Larsen et al., 2010), and $\beta$-glucosidase (Larsen and Aulrich, 2012). In addition, on 2 occasions during the grazing season when all cows were grazing full time (July 4 and August 29) milk was sampled from all cows during 2 consecutive milkings (am and pm), bulked in proportion to yield, and subsequently analyzed for milk fatty acid concentrations as described by Purcell et al. (2016a).

Cow BW was recorded automatically after each milking and an average BW calculated for each week. Body condition score was assessed fortnightly by trained operators using a 5-point scale (Edmonson et al., 1989), where $1=$ emaciated and $5=$ extremely fat. Blood samples were taken from the tail vein of each cow between 0900 and $1000 \mathrm{~h}$, at d 5, 15 ( $\pm 1 \mathrm{~d} ; \pm \mathrm{SD}), 29$ and $43( \pm 3 \mathrm{~d})$ postcalving (designated wk 1, 2, 4, and 6). Blood samples for plasma analysis were centrifuged immediately $\left(1,810 \times g\right.$ for $30 \mathrm{~min}$ at $\left.17^{\circ} \mathrm{C}\right)$, while samples for serum analysis were placed in a fridge at $4^{\circ} \mathrm{C}$ for 24 $\mathrm{h}$, before being centrifuged as described above. Samples of plasma and serum recovered were stored at $-20^{\circ} \mathrm{C}$ until analyzed for a range of metabolites: total protein, albumin, glucose, aspartate aminotransferase, and urea were determined according to standard procedures (Siemens Diagnostics Clinical Methods for ADVIA 1800); nonesterified fatty acids (NEFA) were determined using the Wako, NEFA C ACS-ACOD assay method; BHB was determined according to Harano et al. (1985); fructosamine was determined by a colorimetric assay (reduction of nitrotetrazolium-blue), Roche Diagnostics GmbH, Mannheim, Germany; isocitrate dehydrogenase and malate dehydrogenase activity were analyzed according to Wiking et al. (2008); and glutamate dehydrogenase activity was analyzed according to Schmidt and Schmidt (1995). All analyses were performed using an autoanalyzer, ADVIA 1800 Chemistry System (Siemens Medical Solutions, Tarrytown, NY).

\section{Feed Analysis}

Grass silage offered was sampled daily and analyzed for oven DM, and a fresh silage sample was analyzed weekly for gross energy, $\mathrm{N}, \mathrm{pH}$, ammonia $\mathrm{N}$, and volatile components. Dried samples were retained weekly, bulked for each 2-wk period, and subsequently analyzed for ADF, NDF, and ash concentrations. On one occasion each week during the grazing season, a single herbage sample was taken from the paddock that cows were about to access that afternoon (harvested from 15 
locations within each plot to a height of approximately $6 \mathrm{~cm}$ using battery-operated hand shears). On each occasion a fresh sample of grass was analyzed for ME content using near-infrared reflectance spectroscopy as described by Park et al. (1998) for grass silage, but using a calibration equation developed for fresh grass, and a separate sample dried at $85^{\circ} \mathrm{C}$ for oven DM determination. The remainder of the sample was dried at $60^{\circ} \mathrm{C}$ for $48 \mathrm{~h}$, with the dried samples bulked for each 2-wk period and analyzed for ADF, NDF, N, watersoluble carbohydrate, and ash concentrations. In addition, concentrates offered were sampled weekly, with samples bulked for each 2-wk period. Bulked samples were analyzed for oven DM, N, ADF, NDF, gross energy, and ash. The feedstuffs offered were analyzed as described by Purcell et al. (2016b).

\section{Statistical Analysis}

Six cows did not complete $200 \mathrm{~d}$ on the study [due to injury ( $\mathrm{n}=2$ : medium HOL and low HOL], testing positive for Johne's disease (Mycobacterium avium ssp. paratuberculosis; medium HOL), unexplained death (medium SR $\times \mathrm{J} / \mathrm{HOL}$ ), and a collapsed udder ligament (low $\mathrm{SR} \times \mathrm{J} / \mathrm{HOL}$ ), and their data were excluded from the statistical analysis. Data for DMI (mean for each of the early and late lactation periods when cows were fully housed), milk yield, milk constituent yields, milk composition (mean for the lactation), BW, BCS, and reproductive performance (continuous data) were analyzed according to a 2 (genotype) $\times 2$ (system) factorial arrangement using ANOVA. The following measures were used as covariates within the analysis: lactation length (DIM) and parity for the analysis of milk yield and milk constituent yield data; pre-experimental BW and BCS (difference from the mean value within each genotype) for the analysis of BW and BCS data; days housed and parity for the analysis of intake data. Weekly fat plus protein yield, BW data, and fortnightly BCS data (until wk 44 of lactation) were also analyzed using repeated measures REML variance component analysis. The model included the following terms as fixed effects: parity (for fat + protein yield only) + (pre-experimental $\mathrm{BW}$ and $\mathrm{BCS}$, for $\mathrm{BW}$ and $\mathrm{BCS}$ only: difference from the mean within each genotype) + week of lactation (time) + genotype + system + time $\times$ genotype + time $\times$ system + time $\times$ genotype $\times$ system, whereas cow, and cow within time, were used as random effects. The effect of genotype and concentrate system on milk fatty acid content was analyzed using a similar model, but with week of lactation replaced by sampling occasion ( 1 or 2 ). Similarly, milk and blood biomarker data were analyzed using a similar model, week of lactation referring to wk 1, 2, 4, and 6 postpartum. Binomial health data were analyzed as a binomial distribution within a generalized linear model (genotype + system + genotype $\times$ system $)$, where the $P$-values generated were chi-probabilities. All data were analyzed using GenStat (16th edition, VSN International, Hemel Hempstead, UK).

\section{RESULTS}

The grass silages offered during both early and late lactation (Table 1) were well fermented, had moderate protein contents (133 and $131 \mathrm{~g} / \mathrm{kg}$ of DM, respectively), whereas the former had a numerically higher ME content than the latter (11.1 and $10.4 \mathrm{MJ} / \mathrm{kg}$ of DM). Herbage offered during the grazing period to cows on the low and medium systems had a similar composition, reflecting similar grazing intensities with each concentrate input system. The concentrate offered during the winter and grazing periods had an average CP concentration of 202 and $196 \mathrm{~g} / \mathrm{kg}$ of DM, respectively.

No genotype $\times$ system interactions were present within any of the data presented in Tables 2, 3 and 5. Holstein cows had higher silage $(P=0.016)$, concentrate $(P<0.008)$, and total $(P<0.008)$ DMI than SR $\times \mathrm{J} / \mathrm{HOL}$ cows during the early lactation period, but not $(P>0.05)$ during the late lactation period (Table 2 ). Cows on the medium system had higher concentrate and total DMI than those on the low system during both early lactation $(P<0.001)$ and late lactation $(P$ $<0.001$ and $P=0.031$ for concentrates and total DMI, respectively). Intake per kilogram of metabolic BW did not differ between genotype in either early or late lactation, while being higher for cows on the medium system than the low system in early lactation $(P<0.001)$. Total concentrate intake over the full lactation did not differ between genotypes $(P=0.331)$, but was higher with the medium compared with the low system (769 vs. $1,902 \mathrm{~kg}$ of DM/cow, respectively; $P<0.001$ ).

Whereas full lactation milk yield was higher for the HOL cows $(P<0.001), \mathrm{SR} \times \mathrm{J} / \mathrm{HOL}$ cows produced milk with a higher fat and protein concentration (Table 3 ). Thus, genotype had no effect on fat yield or fat plus protein yield, although protein yield was lower $(P<$ $0.032)$ and ECM yield $(P=0.070)$ tended to be lower with the SR $\times \mathrm{J} / \mathrm{HOL}$ cows. Somatic cell counts were 107,000 and 162,000 per milliliter of milk for the HOL and SR $\times \mathrm{J} / \mathrm{HOL}$ cows, respectively, with SCS per milliliter $\left(\log _{\mathrm{e}}\right.$ basis) being higher $(P<0.021)$ for the latter, whereas SCS per kilogram of milk solids ( $\log _{\mathrm{e}}$ basis) tended to be higher $(P=0.063)$. System had no effect on either milk fat or milk lactose content $(P=0.534$ and 0.427 , respectively), whereas milk protein content 


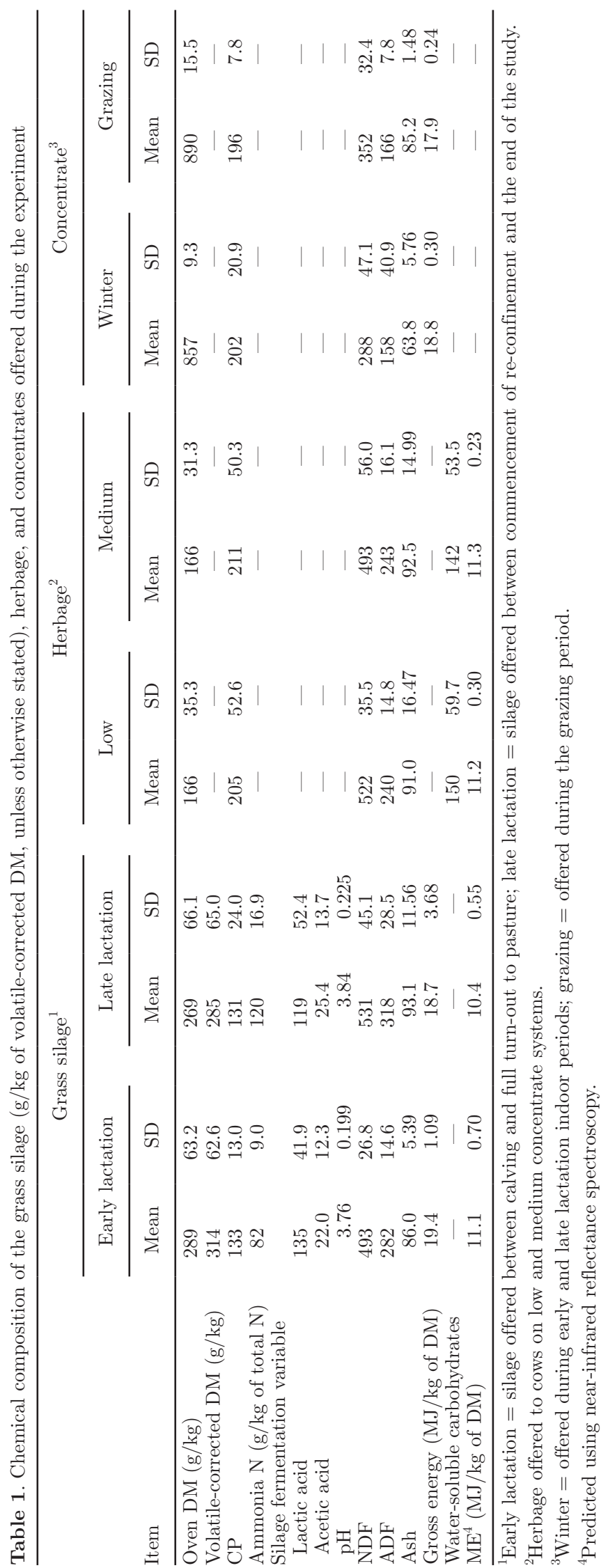

$(P=0.070)$ tended to be higher with the medium system. However, cows on the medium system produced a greater yield of milk, fat, protein, fat plus protein, and ECM $(P<0.001)$ than cows on the low system. Somatic cell counts were 126,000 and 145,000 per milliliter with the low and medium systems, respectively, with system having no effect on SCS (either per $\mathrm{mL}$ or per $\mathrm{kg}$ of milk solids).

The lactation curve for daily fat plus protein yield (weekly over the first $44 \mathrm{wk}$ of lactation) for cows of each genotype on the low and medium systems are presented in Figure 1. Although a system $\times$ week of lactation interaction $(P<0.001)$ was observed, no genotype $x$ week of lactation interaction was observed $(P=0.103)$.

Genotype had no effect $(P>0.05)$ on concentrations of C14:0, C16:0, and C18:0 fatty acids in milk during the grazing season, although HOL cows produced milk with a lower total SFA content than $\mathrm{SR} \times \mathrm{J} / \mathrm{HOL}$ cows $(P<0.001 ;$ Table 3$)$. In contrast, $\mathrm{SR} \times \mathrm{J} / \mathrm{HOL}$ cows produced milk with a lower total MUFA content than the HOL cows $(P<0.002)$. Although $\mathrm{SR} \times \mathrm{J} / \mathrm{HOL}$ cows produced milk with a lower C18:2 cis-9,trans-11 (CLA) content than HOL cows $(P<0.001)$, the total PUFA content of the milk produced was unaffected by genotype. Concentrate system had no effect on C14:0, C16:0, and C18:0 fatty acid concentrations of milk, or on the total SFA content of the milk produced. However, cows on the low system produced milk with a higher total MUFA $(P=0.034)$ content than those on the medium system, and a higher $\mathrm{C} 18: 2$ cis-9,trans-11 fatty acid content $(P=0.003)$, although concentrations of PUFA were unaffected by system.

A trend was observed for a genotype $\times$ system interaction for mean $\mathrm{BW}(P=0.064)$, nadir $\mathrm{BW}(P=$ $0.094)$, and BW loss to nadir $(P=0.094)$, but not for any other parameter presented in Table 4. HolsteinFriesian cows were heavier than $\mathrm{SR} \times \mathrm{J} / \mathrm{HOL}$ cows at 100 and $200 \mathrm{~d}$ postcalving $(P<0.001)$, and at nadir BW $(P<0.001)$, but not at calving or at drying off. Days to nadir BW $(P=0.001)$ and $\mathrm{BW}$ loss to nadir $(P=0.079)$ were greater for the $\mathrm{SR} \times \mathrm{J} / \mathrm{HOL}$ cows. The SR $\times$ J/HOL cows had a higher BCS than HOL cows during all measurement periods detailed in Table $4(P<0.001)$. Cows on the low system were lighter than cows on the medium system at $100 \mathrm{~d}(P<0.001)$ postcalving, and at drying off $(P<0.004)$, while having a lower nadir BW $(P<0.001)$ and greater BW loss to nadir $(P<0.001)$ than those on the medium system. However, system had no effect on BCS at any of the time points presented in Table $4(P>0.05)$.

The effects of genotype and system on cow BW and BCS during the first $44 \mathrm{wk}$ of lactation are presented in Figures 2 and 3, respectively, with both parameters 
Table 2. Effects of cow genotype and concentrate system on DMI ( $\mathrm{kg} / \mathrm{cow}$ per day, unless otherwise stated $)^{1}$

\begin{tabular}{|c|c|c|c|c|c|c|c|c|}
\hline Item & \multicolumn{2}{|c|}{ Genotype $^{2}$} & SEM & $P$-value & \multicolumn{2}{|c|}{ System } & SEM & $P$-value \\
\hline \multicolumn{9}{|l|}{ Early-lactation intake $^{3}$} \\
\hline Concentrate & 9.0 & 8.5 & 0.17 & $<0.008$ & 5.0 & 12.4 & 0.17 & $<0.001$ \\
\hline Total & 18.9 & 17.6 & 0.34 & $<0.008$ & 15.7 & 20.8 & 0.34 & $<0.001$ \\
\hline $\begin{array}{l}\text { Total }(\mathrm{kg} / \mathrm{cow} \text { per day per } \mathrm{kg} \\
\left.\text { of } \mathrm{BW}^{0.75}\right)\end{array}$ & 0.163 & 0.159 & 0.0024 & 0.115 & 0.141 & 0.181 & 0.0024 & $<0.001$ \\
\hline \multicolumn{9}{|l|}{ Late lactation ${ }^{4}$} \\
\hline Grass silage & 13.4 & 13.0 & 0.25 & 0.178 & 14.2 & 12.3 & 0.24 & $<0.001$ \\
\hline Concentrate & 4.8 & 4.7 & 0.06 & 0.259 & 3.3 & 6.2 & 0.06 & $<0.001$ \\
\hline Total & 18.3 & 17.7 & 0.30 & 0.175 & 17.5 & 18.4 & 0.29 & 0.031 \\
\hline $\begin{array}{l}\text { Total }(\mathrm{kg} / \mathrm{cow} \text { per day per } \mathrm{kg} \\
\left.\text { of } \mathrm{BW}^{0.75}\right)\end{array}$ & 0.149 & 0.151 & 0.0022 & 0.500 & 0.151 & 0.151 & 0.0022 & 0.720 \\
\hline $\begin{array}{l}\text { Full-lactation concentrate intake } \\
(\mathrm{kg} \text { of } \mathrm{DM} / \mathrm{cow})\end{array}$ & 1,348 & 1,322 & 31.4 & 0.331 & 769 & 1,902 & 31.8 & $<0.001$ \\
\hline
\end{tabular}

${ }^{1}$ No genotype $\times$ system interactions $(P>0.05)$ were present for any of the variables presented.

${ }^{2} \mathrm{HOL}=$ Holstein dairy cows; $\mathrm{SR} \times \mathrm{J} / \mathrm{HOL}=$ Swedish Red $\times$ Jersey $/$ Holstein crossbred.

${ }^{3}$ Early lactation: calving to start of turnout.

${ }^{4}$ Late lactation: full-time rehousing until drying off.

varying with time. Although there was no genotype $\times$ system $(P=0.445)$ or system $\times$ time $(P=0.118)$ interaction for $\mathrm{BW}$, a genotype $\times$ time interaction $(P$
$<0.001)$ was present. No interactions were observed between genotype, system, or time within the BCS data $(P>0.1)$.

Table 3. Effects of cow genotype and concentrate system on full-lactation milk production performance throughout the lactation, and on key milk fatty acid proportions (g/100 g of total fatty acids identified) in milk sampled on 2 occasions during the experiment (July 4 and August 28$)^{1}$

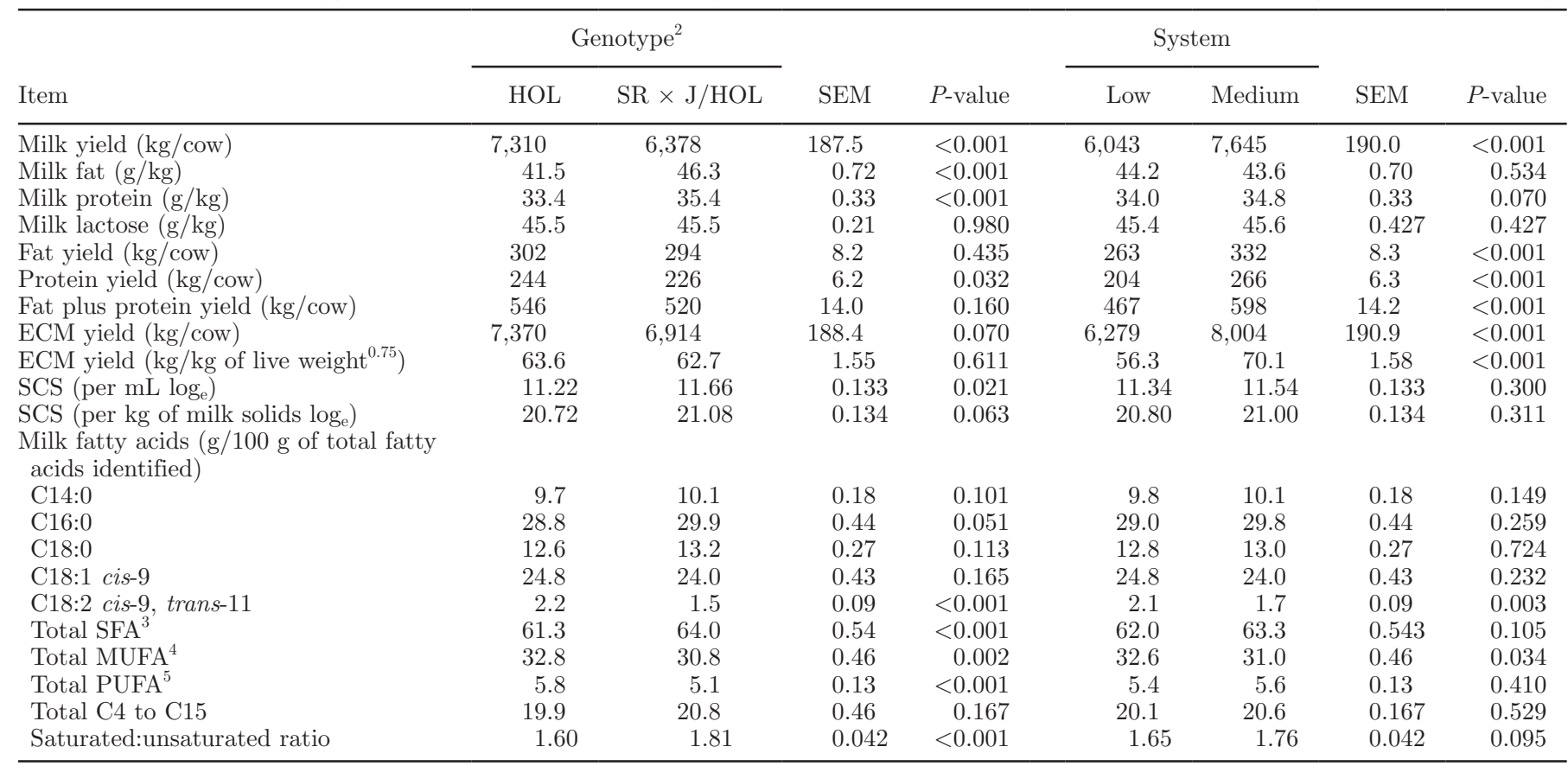

${ }^{1}$ No genotype $\times$ system interactions $(P>0.05)$ were present for any of the variables presented.

${ }^{2} \mathrm{HOL}=$ Holstein dairy cows; $\mathrm{SR} \times \mathrm{J} / \mathrm{HOL}=$ Swedish Red $\times$ Jersey/Holstein crossbred.

${ }^{3}$ Sum of C4:0, C6:0, C8:0, C10:0, C11:0, C12:0, C13:0, C14:0, C15:0, C16:0, C17:0, C18:0, C20:0, C21:0, C22:0, C23:0, and C24:0.

${ }^{4}$ Sum of C14:1, C15:1, C16:1, C17:1, C18:1 cis-9, C18:1 trans-9, C20:1 cis-11, C22:1 cis-13, and C24:1 cis.

${ }^{5}$ Sum of C18:2, C18:2 cis-9,trans-11, C18:2 trans-6, C18:3n-3, C18:3n-6, C20:2 cis-11,14, C20:3 cis-11,14, C20:3 cis-8,11,14, C20:4n-6, C20:5n-3, $\mathrm{C} 22: 2$ cis-13,16, and C22:6n-3. 


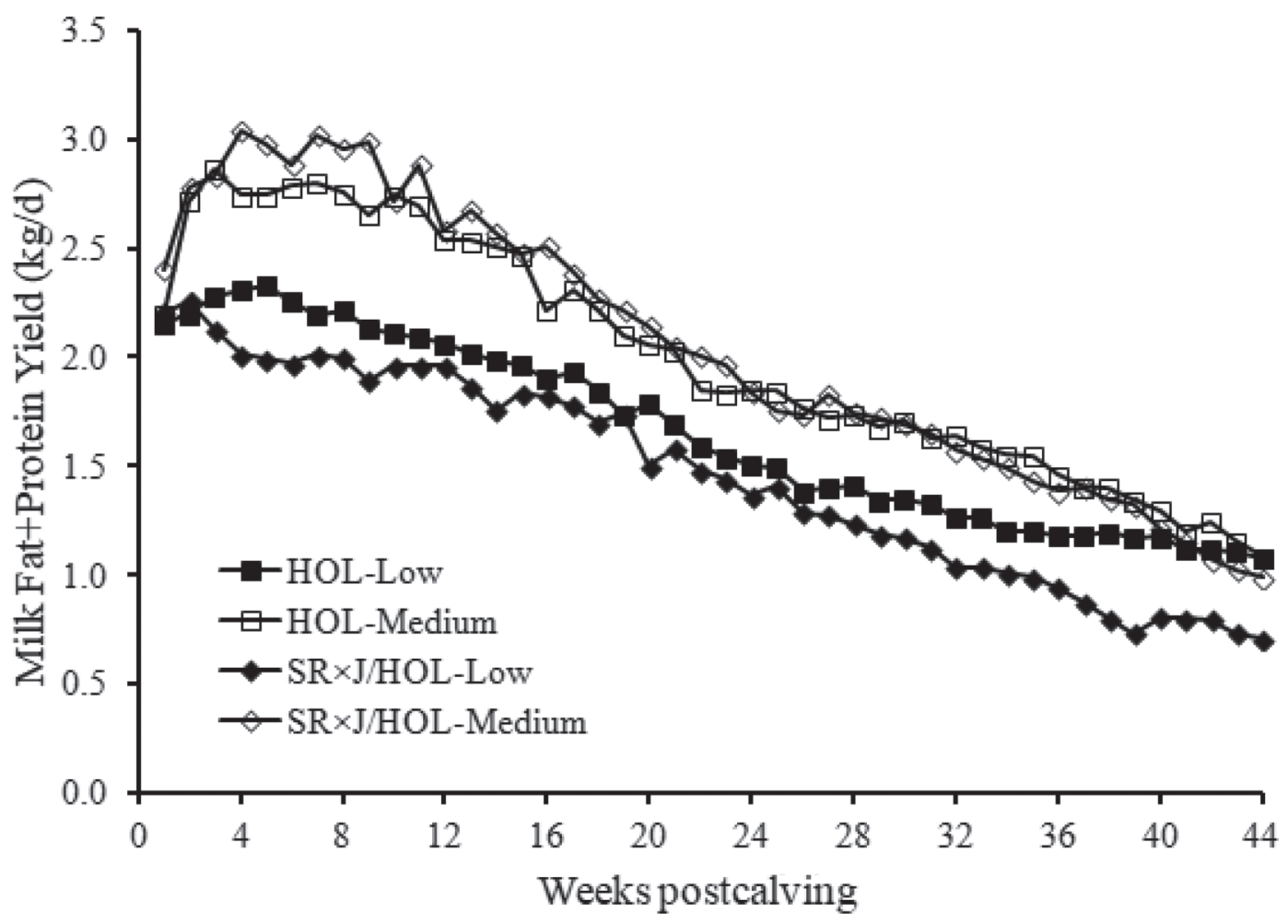

Figure 1. Effect of cow genotype [Holstein $(\mathrm{HOL})$ and Swedish Red $\times$ Jersey/Holstein crossbred $(\mathrm{SR} \times \mathrm{J} / \mathrm{HOL})]$ and concentrate input system (low and medium) on fat + protein yield during the first 44 wk of lactation.

The effect of genotype and system on several milk and blood biomarkers are presented in Table 5. Holstein cows had lower isocitrate $(P=0.018)$ concentrations in milk than $\mathrm{SR} \times \mathrm{J} / \mathrm{HOL}$ cows and lower glucose, fructosamine, albumin $(P<0.001)$, and $\operatorname{BHB}(P=$ $0.021)$ concentrations in blood. Milk and blood from cows on the low system had higher BHB $(P<0.001$ and $P=0.010$, respectively) concentrations, and milk had a higher isocitrate $(P=0.005)$ concentration than that from cows on the medium system. Glucose-6-phosphate $(P=0.034)$ and $N$-acetyl- $\beta$-D-glucosaminidase $(P=0.030)$ in milk, and total protein $(P<0.001)$,

Table 4. Effects of cow genotype and concentrate system on BW and BCS of cows throughout lactation

\begin{tabular}{|c|c|c|c|c|c|c|c|c|c|c|}
\hline Item & \multicolumn{2}{|c|}{ Genotype $^{1}$} & SEM & $P$-value & \multicolumn{2}{|c|}{ System } & SEM & $P$-value & \multicolumn{2}{|c|}{ Interaction } \\
\hline \multicolumn{11}{|l|}{ BW (kg) } \\
\hline At calving & 568 & 549 & 8.9 & 0.188 & 553 & 563 & 8.9 & 0.451 & 13.9 & 0.662 \\
\hline At $100 \mathrm{~d}$ postcalving & 553 & 519 & 4.6 & $<0.001$ & 522 & 550 & 4.6 & $<0.001$ & 6.5 & 0.136 \\
\hline At 200 d postcalving & 561 & 517 & 4.7 & $<0.001$ & 533 & 545 & 4.8 & 0.075 & 6.7 & 0.138 \\
\hline Days to nadir & 88 & 135 & 9.6 & 0.001 & 114 & 109 & 9.7 & 0.711 & 13.6 & 0.527 \\
\hline Loss to nadir & 44 & 54 & 4.2 & 0.079 & 59 & 38 & 4.2 & $<0.001$ & 6.0 & 0.094 \\
\hline \multicolumn{11}{|l|}{$\mathrm{BCS}$} \\
\hline Mean & 2.16 & 2.42 & 0.023 & $<0.001$ & 2.26 & 2.31 & 0.023 & 0.149 & 0.033 & 0.257 \\
\hline At calving & 2.29 & 2.51 & 0.031 & $<0.001$ & 2.40 & 2.40 & 0.031 & 0.893 & 0.044 & 0.772 \\
\hline At $100 \mathrm{~d}$ postcalving & 2.20 & 2.42 & 0.028 & $<0.001$ & 2.30 & 2.32 & 0.028 & 0.620 & 0.039 & 0.564 \\
\hline At $200 \mathrm{~d}$ postcalving & 2.08 & 2.37 & 0.034 & $<0.001$ & 2.19 & 2.26 & 0.034 & 0.206 & 0.049 & 0.397 \\
\hline
\end{tabular}

${ }^{1} \mathrm{HOL}=$ Holstein dairy cows; SR $\times \mathrm{J} / \mathrm{HOL}=$ Swedish Red $\times$ Jersey/Holstein crossbred. 


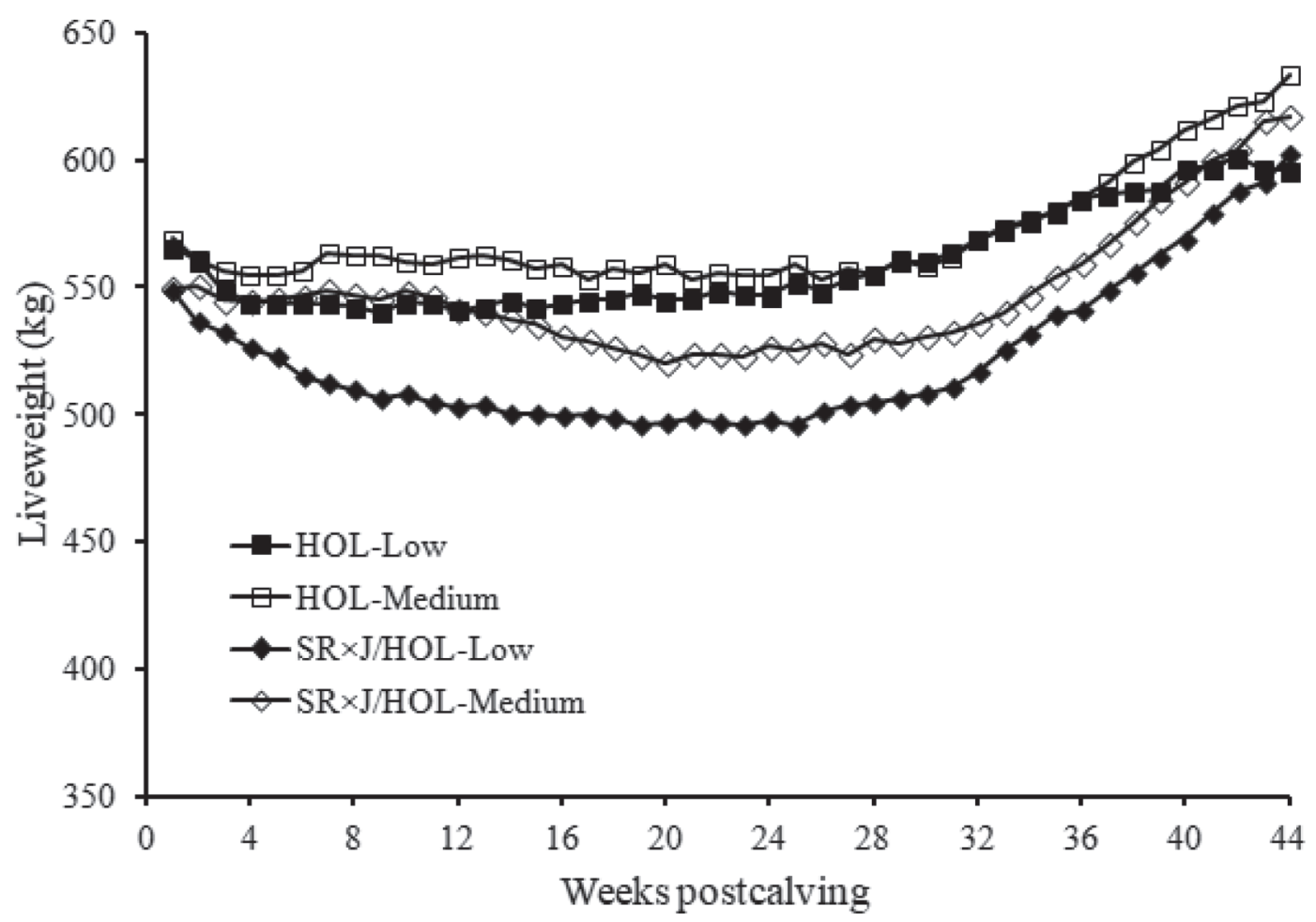

Figure 2. Effect of cow genotype [Holstein $(\mathrm{HOL})$ and Swedish Red $\times$ Jersey/Holstein crossbred $(\mathrm{SR} \times \mathrm{J} / \mathrm{HOL})]$ and concentrate input system (low and medium) on cow live weight during the first 44 wk of lactation.

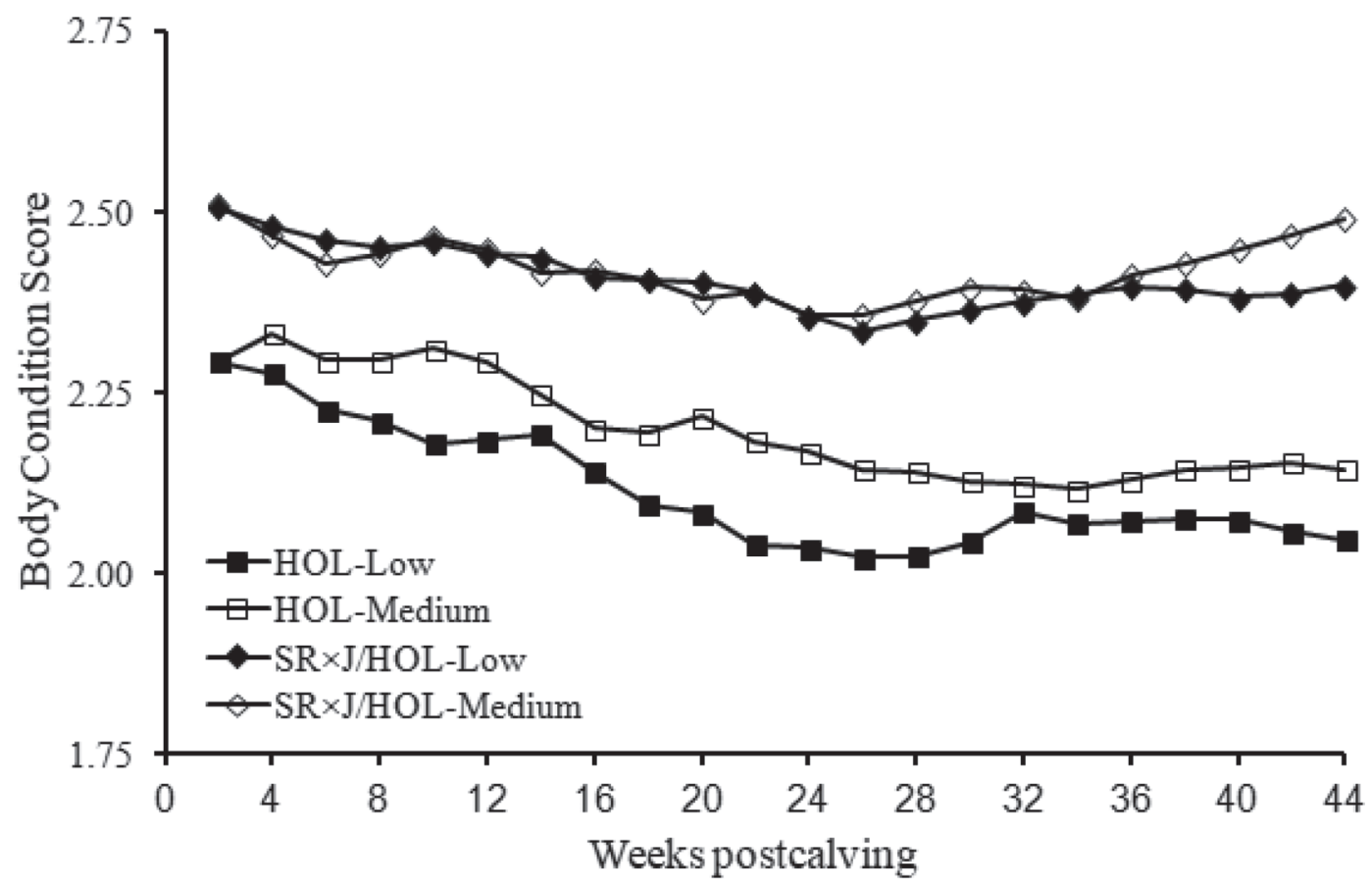

Figure 3. Effect of cow genotype [Holstein $(\mathrm{HOL})$ and Swedish Red $\times$ Jersey/Holstein crossbred $(\mathrm{SR} \times \mathrm{J} / \mathrm{HOL})]$ and concentrate input system (low and medium) on cow BCS during the first 44 wk of lactation. 
Table 5. Effects of cow genotype and concentrate system on milk and blood biomarker concentrations (mean values for samples collected at wk $1,2,4$, and 6 postcalving) $)^{1}$

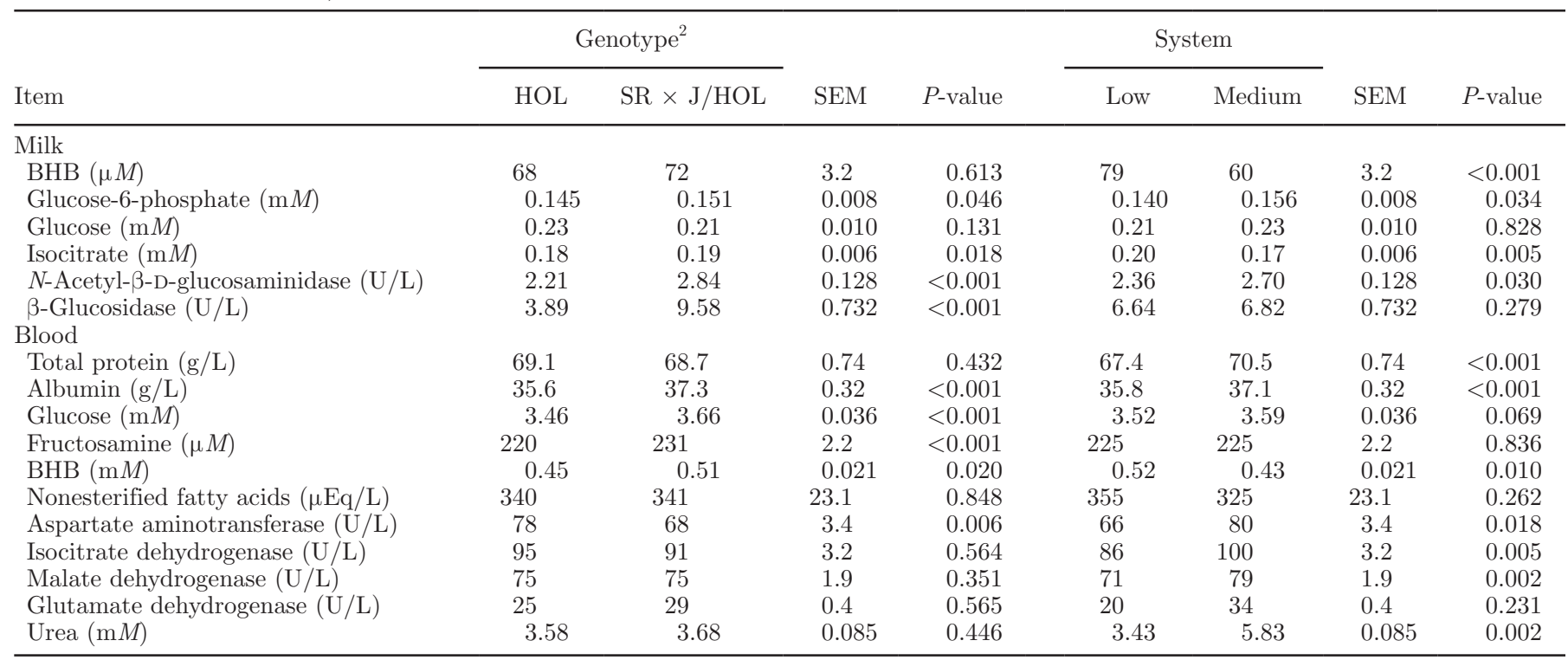

${ }^{1}$ No genotype $\times$ system interactions $(P>0.05)$ were present for any of the variables presented.

${ }^{2} \mathrm{HOL}=$ Holstein dairy cows; $\mathrm{SR} \times \mathrm{J} / \mathrm{HOL}=$ Swedish Red $\times$ Jersey $/$ Holstein crossbred.

albumin $(P<0.001)$, urea $(P=0.002)$, aspartate aminotransferase $(P=0.018)$, isocitrate dehydrogenase $(P$ $=0.005)$, and malate dehydrogenase $(P=0.002)$ in blood were lower with the low compared with medium system cows.

There was a lower incidence of mastitis $(P=0.003)$ and ovarian disorders $(P=0.007)$ in $\mathrm{SR} \times \mathrm{J} / \mathrm{HOL}$ cows than HOL cows (Table 6 ), whereas system had no effect on any of the health parameters presented.

\section{DISCUSSION}

This experiment involved a comparison of 4 treatments [2 (cow genotype) $\times 2$ (systems)] over 1 full lactation While grassland-based systems studies should ideally be compared over multiple lactations to take account of year-to-year variation in seasonal weather patterns, and their effects on herbage production and utilization, often this is not possible. Nevertheless, single lactation systems comparisons have been made previously (Gordon et al., 2000; Vance et al., 2012a), and provided the systems being examined are sufficiently diverse, as in the current experiment, their outcomes can provide robust information on the relative performance of cows within contrasting systems.

\section{Feed Intakes}

Two contrasting systems were established, with these differing in total concentrate DMI $(769$ and $1,902 \mathrm{~kg}$ of $\mathrm{DM} / \mathrm{cow}$, for the low and medium systems, respectively). As a consequence, total DMI was higher with the medium system during the housed periods in early and late lactation.

Few studies have examined the intakes of 3-breed crossbred cows. In one exception, Hazel et al. (2013)

Table 6. Effects of cow genotype and concentrate system on cow health (proportion of cows with at least 1 treatment)

\begin{tabular}{|c|c|c|c|c|c|c|c|c|}
\hline \multirow{2}{*}{$\begin{array}{l}\text { Proportion of cows with } \\
\text { at least } 1 \text { treatment for: }\end{array}$} & \multicolumn{2}{|c|}{ Genotype $^{2}$} & \multirow[b]{2}{*}{ SEM } & \multirow[b]{2}{*}{$P$-value } & \multicolumn{2}{|c|}{ System } & \multirow[b]{2}{*}{ SEM } & \multirow[b]{2}{*}{$P$-value } \\
\hline & HOL & $\mathrm{SR} \times \mathrm{J} / \mathrm{HOL}$ & & & Low & Medium & & \\
\hline Mastitis & 0.26 & 0.06 & 0.060 & 0.033 & 0.16 & 0.17 & 0.063 & 0.908 \\
\hline Metabolic disease & 0.13 & 0.03 & 0.043 & 0.139 & 0.03 & 0.13 & 0.043 & 0.127 \\
\hline Ovarian dysfunction & 0.61 & 0.28 & 0.083 & 0.007 & 0.50 & 0.39 & 0.083 & 0.361 \\
\hline Lameness & 0.10 & 0.13 & 0.055 & 0.721 & 0.16 & 0.06 & 0.054 & 0.237 \\
\hline
\end{tabular}

${ }^{1}$ A genotype $\times$ system interaction $(P<0.05)$ was present for the proportion of cows with at least 1 case of metabolic disease $(P=0.019)$.

${ }^{2} \mathrm{HOL}=$ Holstein dairy cows; $\mathrm{SR} \times \mathrm{J} / \mathrm{HOL}=$ Swedish Red $\times$ Jersey $/$ Holstein crossbred. 
compared the intakes of Montbéliarde $\times$ Jersey/Holstein cows with purebred Holstein cows over the first $150 \mathrm{~d}$ of lactation and found intake to be unaffected by genotype. While Hynes et al. (2016) presented data from a nutrient utilization study showing Holstein cows to have higher intakes than Swedish Red $\times$ Holstein/ Jersey cows, this study only involved 6 cows of each genotype. Larger scale studies comparing the intake potential of Swedish Red versus Holstein cows, or Swedish Red crossbreed cows versus Holstein cows have not been identified, and consequently little is known about the comparative intakes of these 2 genotypes. However, several studies have compared the intakes of Holstein versus Jersey $\times$ Holstein crossbred cows. When housed indoors and offered diets based on conserved forage (Heins et al., 2008a; Vance et al., 2012a, 2013), and while grazing (Prendiville et al., 2009; Vance et al., 2012b, 2013) intakes of Jersey $\times$ Holstein crossbred cows and purebred Holstein cows were found to be similar. Indeed, Prendiville et al. (2009) found the Jersey $\times$ Holstein-Friesian cows had a higher intake/100 kg of BW than the Holstein cows, in agreement with the earlier findings of Gonzalez-Verdugo et al. (2005). These higher intakes per unit of BW may be attributed to several factors, including differences in grazing behavior between genotypes (Prendiville et al., 2010a; Vance et al., 2012b) and crossbred cows having a heavier gastrointestinal tract (as a proportion of BW) than Holstein cows (Beecher et al., 2014). Nevertheless, in the current study SR $\times \mathrm{J} / \mathrm{HOL}$ cows had a lower total DMI than HOL cows during the early lactation housed period (1.22 kg lower), but not during the late lactation housing period, suggesting that some of the enhanced intake potential associated with Jersey $\times$ Holstein crossbred cows was lost when moving to $50 \%$ Swedish Red genetics in the 3 -breed cross. This suggestion was supported in that intake per kilogram of $\mathrm{BW}^{0.75}$ did not differ between genotypes in either early or late lactation.

\section{Milk Production and Composition}

Although cows of each genotype on each of the low and medium systems had a different mean DIM, the use of full-lactation DIM as a covariate within the statistical analysis allows milk production data to be expressed on a common lactation length basis, namely $289 \mathrm{~d}$ (the mean number of days for all cows on the study). Although the $\mathrm{SR} \times \mathrm{J} / \mathrm{HOL}$ cows produced substantially less milk $(932 \mathrm{~kg})$ than the HOL cows, they produced milk with a higher fat $(4.8 \mathrm{~g} / \mathrm{kg}$ higher $)$ and protein $(2.0 \mathrm{~g} / \mathrm{kg}$ higher $)$ content. Nevertheless, milk protein yield was lower with the former, ECM yield tended to be lower $(P=0.07)$, whereas fat plus protein yield was unaffected. This was reflected in concentrate intakes ( $\mathrm{kg}$ of DM basis) per kilogram of milk of 0.18 and 0.21 , for HOL and SR $\times$ J/HOL, respectively, whereas respective values per kilogram of fat plus protein yield were 2.47 and 2.54. While the Jersey component of the breed may have contributed to the lower milk yield, Jersey $\times$ Holstein cows managed on low and moderate concentrate systems produced only 310 and $625 \mathrm{~kg}$ less milk than Holstein cows in previous studies at this institute (Vance et al., 2012a and 2013, respectively). In addition, given that the average lactation milk yield of the Swedish Red breed in Sweden is 8,730 kg (European Red Dairy Breed Association, 2009), the reduction in milk yield seen within the current study was surprising.

The higher fat and protein content of milk produced by the $\mathrm{SR} \times \mathrm{J} / \mathrm{HOL}$ cows in this study can be attributed to several factors. These include the $25 \%$ contribution of Jersey genetics (Jersey cows normally produce milk with a higher fat and protein content than Holstein cows: Rastani et al., 2001; White et al., 2001; Aikman et al., 2008) and the high milk fat and protein contents observed with the Swedish Red breed (4.3\% fat and 3.5\% protein in Sweden; European Red Dairy Breed Association, 2009). The overall trends are in general agreement with studies involving Scandinavian Red $\times$ Holstein cows and Jersey $\times$ Holstein cows (Auldist et al., 2007; Heins and Hansen, 2012; Vance et al., 2012a; Prendiville et al., 2009), in which the fat plus protein yield or solids-corrected milk yield of the crossbred cows was either similar to, or slightly lower than, that of Holstein cows. Nevertheless, in the latter study Jersey $\times$ Holstein crossbred cows had a higher milk solids yield $/ \mathrm{kg}$ of $\mathrm{BW}$, and a higher milk solids yield $/ \mathrm{kg}$ of DMI (Prendiville et al., 2009), than the Holstein cows, indicating an overall higher efficiency with the crossbred cows. Although this is driven in part by the lighter crossbred cows having a lower maintenance requirement and a higher intake per kilogram of metabolic BW, it is also possible that differences in digestibility efficiency and rumen microbial populations (Beecher et al., 2014) could be contributing factors. However, ECM per kilogram of metabolic BW was unaffected by genotype in the current study, suggesting similar levels of efficiency with each of the 2 genotypes. Nevertheless, this experiment suggests that $\mathrm{SR} \times \mathrm{J} /$ HOL cows can compete with HOL cows in terms of milk solids production within both low and medium concentrate grass-based milk production systems.

Cows on the medium system produced 1,602 kg more milk than those on the low system, a milk yield response of $1.24 \mathrm{~kg}$ milk/ $\mathrm{kg}$ extra concentrate, with this value within the range of responses to concentrates 
observed with higher yielding cows offered grass/grass silage-based diets (Vance et al., 2012a). Concentrate intakes ( $\mathrm{kg}$ of DM basis) per kilogram of milk were 0.13 and 0.25 for low and medium, respectively, whereas the respective values per kilogram of fat plus protein were 1.65 and 3.18. Few studies comparing crossbred and purebred cows have examined for evidence of a genotype $\times$ nutrition interaction. Although Vance et al. (2012a) observed an interaction for milk production in a study comparing Holstein and Jersey $\times$ Holstein cows, their experiment involved 2 very different levels of nutrition [approximately 0.8 (low) and 2.9 (medium) t of concentrate/cow per lactation]. However, in a separate study involving Holstein and Jersey $x$ Holstein cows managed on systems with concentrate inputs ranging from 466 to $1,467 \mathrm{~kg}$ of $\mathrm{DM} /$ lactation, no evidence of an interaction was observed for any of the milk production parameters (Vance et al., 2013). Similarly, Walsh et al. (2008) found no evidence of a genotype $\times$ nutrition interaction for any of the milk production parameters examined in a study comparing Holstein cows with Montbéliarde and Normande crossbred cows, within 2 management systems differing in concentrate inputs. The findings of the latter 2 studies are in agreement with those of the current study, with no evidence of a genotype $\times$ system interaction for any of the production parameters examined.

The effect of cow genotype on the fatty acid content of milk has been examined in several studies. Palladino et al. (2010) reported significantly higher concentrations of C16:0 fat in milk production by purebred Jersey and Jersey $\times$ Holstein-Friesian cows compared with milk produced by purebred Holstein cows. While this is in agreement with the findings of the current study, White et al. (2001) and Vance et al. (2012a) found no such effect of genotype on C16:0 concentrations. Concentrations of C18:0 were unaffected by genotype, in agreement with the findings of Palladino et al. (2010), although total SFA concentrations were higher with the $\mathrm{SR} \times \mathrm{J} / \mathrm{HOL}$ cows. In agreement with the findings of Vance et al. (2012a), the HOL cows in this study produced milk with a higher CLA concentration than the crossbred cows, perhaps due to the HOL cows having a higher stearoyl-CoA desaturase activity (Palladino et al., 2010), as the conversion of vaccenic acid (trans-11 C18:1) to CLA via stearoyl-CoA desaturase activity is a major source of CLA in milk (Lock and Garnsworthy, 2003). Although some evidence indicates that differences exist between genotypes in relation to milk fatty acid concentrations, the findings are by no means consistent between studies, and it is possible that variations between individual sires within a breed are of greater importance than the variations between breeds or breed types per se.
The concentrate levels adopted with the low and medium systems during the grazing period (1.0 and $4.0 \mathrm{~kg} / \mathrm{cow}$ per d with low and medium, respectively) were not sufficiently different to affect the concentrations of any of the SFA identified. Concentrations of C18:2 cis-9,trans-11 (CLA) were highest with the low system (high grass diet), in agreement with the findings of many other workers (Dhiman et al., 1999; White et al., 2001; Dewhurst et al., 2006). Pasture-based diets are known to be the best substrate for the synthesis of CLA, a consequence of the higher accumulation of vaccenic acid following extensive rumen hydrogenation of both linoleic and linolenic fatty acids (Dewhurst et al., 2006).

\section{Body Tissue Change and Blood and Milk Metabolites}

During the experiment HOL cows were, on average, $30 \mathrm{~kg}$ heavier than $\mathrm{SR} \times \mathrm{J} / \mathrm{HOL}$ cows, whereas the latter had a 0.26 unit higher BCS. Similar trends have been observed in studies involving Jersey $\times$ Holstein Friesian cows (Auldist et al., 2007; Heins et al., 2008a; Vance et al., 2012a). However, in the current study the crossbred cows reached nadir BW later, and lost more BW to nadir than the Holstein cows, resulting in a significant genotype $\times$ time interaction for BW over the lactation period. While this effect was certainly more pronounced with the low system (Figure 2), resulting in a trend for a genotype $\times$ system interaction, crossbred cows on the medium system also experienced a distinct period of BW loss, from approximately wk 12 of lactation, with this corresponding to the mean start of full-time grazing. There is no obvious explanation for these effects, especially as BCS data provided no evidence of increased body tissue mobilization with SR $\times \mathrm{J} / \mathrm{HOL}$ cows than from Holstein cows. Indeed, BCS trends within the current study were similar to those reported by Vance et al. (2013), with both genotypes losing a similar amount of body condition in early lactation, while showing little evidence of BCS gain until approximately wk-25 to 30 of lactation. That the differences between genotypes in $\mathrm{BW}$ were not reflected in $\mathrm{BCS}$ trends might suggest that the BW changes with the $\mathrm{SR} \times \mathrm{J} / \mathrm{HOL}$ cows were in part a "rumen fill" effect associated with their lower DMI in early lactation. It is also possible that there was a greater loss in internal body fat reserves with the crossbred cows, which were not reflected in BCS changes. Indeed, milk and blood biomarker data indicate several distinct differences between genotypes, highlighting that metabolic differences did exist.

For example, plasma BHB concentration, an indicator of fat mobilization, was higher with the SR $\times \mathrm{J} /$ HOL cows, although this was not supported by differ- 
ences in plasma NEFA concentrations between genotypes. In contrast, Horn et al. (2014), in a comparable experimental design observed the opposite, with blood BHB unaffected by cow type (Brown Swiss vs. HolsteinFriesian), whereas plasma NEFA was significantly different. Nevertheless, both BHB and NEFA levels in the present study were moderate compared with values in the literature (e.g., Bjerre-Harpøth et al., 2016), which suggests only moderate levels of fat mobilization, thus supporting the BCS data. In addition, plasma albumin, glucose, and fructosamine concentrations were marginally higher in $\mathrm{SR} \times \mathrm{J} / \mathrm{HOL}$ cows compared with $\mathrm{HOL}$ cows, in accordance with the generally better BCS in $\mathrm{SR} \times \mathrm{J} / \mathrm{HOL}$ cows. Although few studies have been able to demonstrate fructosamine as a useful indicator of energy status in cattle, recently Bjerre-Harpøth et al. (2016) observed a considerable increase due to ruminal infusion of propylene glycol, generally accepted to provide an energy boost. Although previous research comparing different cow genotypes (Holstein and Jersey) has demonstrated that milk indicators (e.g., glucose and BHB) can provide information on cow energy status (Larsen and Moyes, 2015), there were few differences in the current study. One exception was isocitrate, with concentrations higher in milk of SR $\times$ J/HOL compared with Holstein-Friesian cows, reflecting the improved energy status of the latter (BjerreHarpøth et al., 2016). The relatively minor differences between genotypes in blood and milk metabolites were supported by the similar activities of liver enzymes (aspartate aminotransferase, glutamate dehydrogenase, isocitrate dehydrogenase, and malate dehydrogenase), with an increase in their activity in plasma normally attributed to increased metabolic stress, resulting in enzymes being leaked from liver cells to the blood.

In general, cows on the low system were lighter than those on the medium system $(21 \mathrm{~kg}$ lighter, on average), and lost more BW to nadir. This is supported by the lower plasma total protein, albumin, and glucose concentrations, and higher BHB concentrations, which suggest that cows on the low system had a poorer energy status than those on the medium system, although this was not reflected in differences in plasma NEFA levels or BCS across the lactation. Similar trends were observed in the study by Horn et al. (2014) with lower feeding levels. Others have observed plasma NEFA not to be consistent with other indicators of energy balance (Pires et al., 2015). The higher BHB and isocitrate levels in milk of cows on the low system are consistent with the increased BW loss to nadir of cows on this system. Although Larsen et al. (2016) demonstrated that milk metabolites can be used to demonstrated differences in net energy intake (digestibility) between cows, differences can be small, leading these authors to suggest that predictive value of milk metabolites can be enhanced by combining the variables into indices. Although the higher liver enzyme activity with the medium system may reflect the more rapid increase in milk production with this system in early lactation, activities with both systems were low, suggesting normal liver function (e.g., Andersen et al., 2008; Wiking et al., 2008).

\section{Health}

Selection for mastitis resistance has been ongoing within the Scandinavian countries for several decades, with studies comparing Norwegian Red and Holstein cows showing Norwegian Red to have a significantly lower SCS (Begley et al., 2009; Ferris et al., 2014). Similarly, over 5 lactations, Heins and Hansen (2012) found mean SCC of Scandinavian Red $\times$ Holstein cows to be lower than for purebred Holstein cows. However, $\mathrm{SR} \times \mathrm{J} / \mathrm{HOL}$ cows had a higher SCS per milliliter of milk (and tended to have a higher SCS per $\mathrm{kg}$ milk solids) than HOL cows in the present study. This is supported by the higher concentrations of $N$-acetyl- $\beta$ D-glucosaminidase and $\beta$-glucoronidase in milk of SR $\times$ $\mathrm{J} / \mathrm{HOL}$ cows in early lactation, both of these being indicators of subclinical mastitis. Nevertheless, the majority of studies involving comparisons of Holstein-Friesian and Jersey $\times$ Holstein-Friesian cows have reported no difference between genotypes for mean SCS (Heins et al., 2008b; Prendiville et al., 2010b), although Vance et al. (2013) found Jersey crossbred cows to have a higher SCS than Holstein cows. In general, the benefits of hybrid vigor on SCS appear to be low, with VanRaden and Sanders (2003) reporting levels of hybrid vigor for SCC in Holstein, Jersey, and Guernsey crossbred cows to be low and unfavorable, whereas Prendiville et al. (2010b) observed no evidence of hybrid vigor for SCS in Jersey crossbred cows. Nevertheless, the $\mathrm{SR} \times \mathrm{J} / \mathrm{HOL}$ cows had a lower incidence of clinical mastitis than the HOL cows, in agreement with the findings of studies involving Jersey crossbred cows (Heins et al., 2011; Vance et al., 2012a; third-lactation cows). Concentrate input system had no effect on either SCC or mastitis incidence, which is not surprising given that the overall management within these systems was similar.

Whereas Logue et al. (1994) found Jersey $\times$ Holstein crossbred cows to have improved hoof health compared with Holstein cows, Vance et al. (2013) found no such effect, in agreement with the findings of the current study. Whereas system had no effect on hoof health in the current study, the latter authors observed an increase in lameness problems when concentrate input 
levels increased from 466 to $1,467 \mathrm{~kg}$ of $\mathrm{DM} /$ cow per lactation.

\section{CONCLUSIONS}

Whereas the 3-breed rotational crossbred cows used in the current study $(\mathrm{SR} \times \mathrm{J} / \mathrm{HOL})$ had a higher BCS than the HOL cows, they were lighter, tended to lose more BW, had lower DMI, and produced less milk than HOL cows. However, their milk had a higher fat and protein content, meaning that fat plus protein yield was unaffected by genotype. No genotype $\times$ system interaction was observed for any of the milk production parameters, meaning that although the $\mathrm{SR} \times \mathrm{J} / \mathrm{HOL}$ cows were able to compete with the HOL cows within both low and medium concentrate input systems (for milk solids yield), they offered no advantages. However, the crossbred cows had fewer incidences of mastitis and ovarian dysfunction than the HOL cows, highlighting their improved functional traits, with this likely to be due in part to heterosis.

\section{ACKNOWLEDGMENTS}

The authors acknowledge funding from the European Community Financial Participation under the Seventh Framework Program FP7-KBBE.2010.1.2-02, for the Collaborative Project SOLID (Sustainable Organic and Low-Input Dairy Systems: grant agreement No. 266267). Thanks are due to the Dairy Unit staff at AFBI Hillsborough for care of the experimental animals and for assisting with experimental measurements. This study was co-funded by the Department of Agriculture and Rural Development (DARD) in Northern Ireland.

\section{REFERENCES}

Aikman, P. C., C. K. Reynolds, and D. E. Beever. 2008. Diet digestibility, rate of passage, and eating and rumination behaviour of Jersey and Holstein cows. J. Dairy Sci. 91:1103-1114. https://doi .org/10.3168/jds.2007-0724.

Andersen, J. B., C. Ridder, and T. Larsen. 2008. Priming the cow for mobilization in the periparturient period: Effects of supplementing the dry cow with saturated fat or linseed. J. Dairy Sci. 91:1029 1043. https://doi.org/10.3168/jds.2007-0437.

Auldist, M. J., M. F. S. Pyman, C. Grainger, and K. L. Macmillan. 2007. Comparative reproductive performance and early lactation productivity of Jersey $\times$ Holstein cows in predominantly Holstein herds in a pasture-based dairying system. J. Dairy Sci. 90:48564862. https://doi.org/10.3168/jds.2006-869.

Beecher, M., F. Buckley, S. M. Waters, T. M. Boland, D. EnriquezHidalgo, M. H. Deighton, M. O'Donovan, and E. Lewis. 2014. Gastrointestinal tract size, total-tract digestibility, and rumen microflora in different dairy cow genotypes. J. Dairy Sci. 97:3906-3917. https://doi.org/10.3168/jds.2013-7708.

Begley, N., F. Buckley, K. M. Pierce, A. G. Fahey, and B. A. Mallard. 2009. Differences in udder health and immune response traits of Holstein-Friesians, Norwegian Reds, and their crosses in second lactation. J. Dairy Sci. 92:749-757. https://doi.org/10.3168/jds .2008-1356.

Bjerre-Harpøth, V., A. C. Storm, M. Vestergaard, M. Larsen, and T. Larsen. 2016. Effect of postparum propylene glycol allocation to over-conditioned Holstein cows on concentrations of milk metabolites. J. Dairy Res. 83:156-164. https://doi.org/10.1017/ S0022029916000145.

Blottner, S., B. J. Heins, M. Wensch-Dorendorf, L. B. Hansen, and H. H. Swalve. 2011. Brown Swiss x Holstein crossbreds compared with pure Holsteins for calving traits, body weight, backfat thickness, fertility, and body measurements. J. Dairy Sci. 94:1058-1068. https://doi.org/10.3168/jds.2010-3305.

Dechow, C. D., G. W. Rogers, J. B. Cooper, M. I. Phelps, and A. L. Mosholder. 2007. Milk, fat, protein, and somatic cell score and days open among Holstein, Brown Swiss and their crosses. J. Dairy Sci. 90:3542-3549. https://doi.org/10.3168/jds.2006-889.

Dewhurst, R. J., K. J. Shingfield, M. R. F. Lee, and N. D. Scollan. 2006. Increasing the concentrations of beneficial polyunsaturated fatty acids in milk produced by dairy cows in high-forage systems. Anim. Feed Sci. Technol. 131:168-206. https://doi.org/10.1016/j .anifeedsci.2006.04.016.

Dhiman, T. R., G. R. Anand, L. D. Satter, and M. W. Pariza. 1999 Conjugated linoleic acid content of milk from cows fed different diets. J. Dairy Sci. 82:2146-2156. https://doi.org/10.3168/jds.S0022 -0302(99)75458-5.

Edmonson, A. J., I. J. Lean, L. D. Weaver, T. Farver, and G. Webster. 1989. A body condition scoring chart for Holstein dairy cows. J. Dairy Sci. 72:68-78. https://doi.org/10.3168/jds.S0022 $-0302(89) 79081-0$

European Red Dairy Breed Association. 2009. Swedish Red. Accessed Nov. 7, 2017. http://www.red-dairy.com/Swedish.php.

Ferris, C. P., D. C. Patterson, F. J. Gordon, S. Watson, and D. J. Kilpatrick. 2014. Calving traits, milk production, body condition, fertility and survival of Holstein-Friesian and Norwegian red dairy cattle on commercial dairy farms over five lactations. J. Dairy Sci. 97:5206-5218. https://doi.org/10.3168/jds.2013-7457.

Gonzalez-Verdugo, H., J. C. Magofke, and C. Mella. 2005. Productivity, consumption and biological efficiency in New Zealand Friesian cows and $\mathrm{F}_{1}$ (New Zealand Jersey-Friesian) calving in late winter in the Xth region. Chile. Arch. de Medic. Vet. 37:37-47.

Gordon, F. J., C. P. Ferris, D. C. Patterson, and C. S. Mayne. 2000. A comparison of two grassland based systems for autumn calving dairy cows of high genetic merit. Grass Forage Sci. 55:83-96.

Harano, Y., M. Ohtsuki, M. Ida, H. Kojima, M. Harada, T. Okanishi, A. Kashiwagi, Y. Ochi, S. Uno, and Y. Shigeta. 1985. Direct automated assay method for serum or urine levels of ketone bodies. Clin. Chim. Acta 151:177-183.

Hazel, A. R., B. J. Heins, A. J. Seykora, and L. B. Hansen. 2013. Montbéliarde-sired crossbreds compared with pure Holsteins for dry matter intake, production, and body traits during the first 150 days of first lactation. J. Dairy Sci. 96:1915-1923. https://doi.org/ $10.3168 /$ jds.2012-5667.

Hazel, A. R., B. J. Heins, A. J. Seykora, and L. B. Hansen. 2014. Production, fertility, survival, and body measurements of Montbéliarde-sired crossbreds compared with pure Holsteins during their first 5 lactations. J. Dairy Sci. 97:2512-2525. https://doi.org/10 .3168/jds.2013-7063.

Heins, B. J., and L. B. Hansen. 2012. Short communication: Fertility, somatic cell score, and production of Normande x Holstein, Montbéliarde x Holstein, and Scandinavian Red x Holstein crossbreds versus pure Holsteins during their first 5 lactations. J. Dairy Sci. 95:918-924. https://doi.org/10.3168/jds.2011-4523.

Heins, B. J., L. B. Hansen, and A. De Vries. 2012. Survival, lifetime production, and profitability of Normande x Holstein, Montbéliarde x Holstein, and Scandinavian Red x Holstein crossbreds versus pure Holstein. J. Dairy Sci. 95:1011-1021. https://doi.org/10 $.3168 /$ jds.2011-4525.

Heins, B. J., L. B. Hansen, and A. J. Seykora. 2006a. Calving difficulty and still births of pure Holsteins versus crossbreds of Holstein with Normande, Montbéliarde, and Scandinavian Red. J. Dairy Sci. 
89:2805-2810. https://doi.org/10.3168/jds.S0022-0302(06)72357 $-8$.

Heins, B. J., L. B. Hansen, and A. J. Seykora. 2006b. Production of pure Holsteins versus crossbreds of Holstein with Normande, Montbéliarde, and Scandinavian Red. J. Dairy Sci. 89:2799-2804. https://doi.org/10.3168/jds.S0022-0302(06)72356-6.

Heins, B. J., L. B. Hansen, A. J. Seykora, A. R. Hazel, D. G. Johnson, and J. G. Linn. 2008a. Crossbreds of Jersey $\times$ Holstein compared with pure Holsteins for body weight, body condition score, dry matter intake, and feed efficiency during the first one hundred and fifty days of first lactation. J. Dairy Sci. 91:3716-3722. https://doi .org/10.3168/jds.2008-1094.

Heins, B. J., L. B. Hansen, A. J. Seykora, A. R. Hazel, D. G. Johnson, and J. G. Linn. 2011. Short communication. Jersey $\times$ Holstein crossbreds compared with pure Holsteins for production, mastitis and body measurements during the first 3 lactations. J. Dairy Sci. 94:501-506. https://doi.org/10.3168/jds.2010-3232.

Heins, B. J., L. B. Hansen, A. J. Seykora, D. G. Johnson, J. G. Linn, J. E. Romano, and A. R. Hazel. 2008b. Crossbreds of Jersey $\times$ Holstein compared with pure Holsteins for production, fertility, and body and udder measurements during first lactation. J. Dairy Sci. 91:1270-1278. https://doi.org/10.3168/jds.2007-0564.

Heringstad, B., G. Klemetsdal, and J. Ruane. 2000. Selection for mastitis resistance in dairy cattle: A review with focus on the situation in the Nordic countries. Livest. Prod. Sci. 64:95-106. https://doi .org/10.1016/S0301-6226(99)00128-1.

Horn, M., A. Steinwidder, R. Pfister, J. Gasteiner, M. Vestergaard, T. Larsen, and W. Zollitsch. 2014. Do different cow types respond differently to a reduction of concentrate supplementation in an Alpine low-input dairy system? Livest. Sci. 170:72-83. https://doi .org/10.1016/j.livsci.2014.10.006.

Hynes, D. N., S. Stergiadis, A. Gordon, and T. Yan. 2016. Effects of concentrate crude protein content on nutrient digestibility, energy utilisation, and methane emissions in lactating dairy cows fed fresh-cut perennial grass. J. Dairy Sci. 99:8858-8866. https://doi .org/10.3168/jds.2016-11509.

Larsen, T. 2014. Fluorometric determination of free and total isocitrate in bovine milk. J. Dairy Sci. 97:7498-7504. https://doi.org/ $10.3168 /$ jds.2014-8018.

Larsen, T. 2015. Fluorometric determination of free glucose and glucose 6-phosphate in cow's milk and other opaque matrices. Food Chem. 166:283-286. https://doi.org/10.1016/j.foodchem.2014.06 .017 .

Larsen, T., L. Alstrup, and M. R. Weisbjerg. 2016. Minor milk constituents are affected by protein concentration and forage digestibility in the feed ration. J. Dairy Res. 83:12-19. https://doi.org/ 10.1017/S0022029915000692.

Larsen, T., and K. Aulrich. 2012. Optimizing the fluorometric b-glucuronidase assay in ruminant milk for a more precise determination of mastitis. J. Dairy Res. 79:7-15. https://doi.org/10.1017/ S0022029911000720.

Larsen, T., and M. Moyes. 2015. Are free glucose and glucose-6-phosphate in milk indicators of specific physiological states in the cow? Animal 9:86-93. https://doi.org/10.1017/S1751731114002043.

Larsen, T., and N. I. Nielsen. 2005. Fluorometric determination of $\beta$-hydroxybutyrate in milk and blood plasma. J. Dairy Sci. 88:2004-2009. https://doi.org/10.3168/jds.S0022-0302(05)72876 $-9$.

Larsen, T., C. M. Røntved, K. L. Ingvartsen, L. Vels, and M. Bjerring. 2010. Enzyme activity and acute phase proteins in milk utilized as indicators of acute clinical E. coli LPS-induced mastitis. Animal 4:1672-1679. https://doi.org/10.1017/S1751731110000947.

Lock, A. L., and P. C. Garnsworthy. 2003. Seasonal variation in milk conjugated linoleic acid and [Delta]9-desaturase activity in dairy cows. Livest. Prod. Sci. 79:47-59.

Logue, D. N., J. E. Offer, and J. J. Hyslop. 1994. Relationship of diet, hoof type and locomotion score with lesions of the sole and white line in dairy cattle. Anim. Prod. 59:173-181.

Malchiodi, F., A. Cecchinato, and G. Bittante. 2014. Fertility traits of purebred Holsteins and 2- and 3-breed crossbred heifers and cows obtained from Swedish Red, Montbéliarde, and Brown Swiss sires. J. Dairy Sci. 97:7916-7926. https://doi.org/10.3168/jds.2014 $-8156$.

McAllister, A. J. 2002. Is crossbreeding the answer to questions of dairy breed utilization? J. Dairy Sci. 85:2352-2357. https://doi .org/10.3168/jds.S0022-0302(02)74315-4.

Miglior, F., B. L. Muir, and B. J. Van Doormaal. 2005. Selection indices in Holstein cattle of various countries. J. Dairy Sci. 88:12551263. https://doi.org/10.3168/jds.S0022-0302(05)72792-2.

Palladino, R. A., F. Buckley, R. Prendiville, J. J. Murphy, J. Callan, and D. A. Kenny. 2010. A comparison between Holstein-Friesian and Jersey dairy cows and their F1 hybrid on milk fatty acid composition under grazing conditions. J. Dairy Sci. 93:2176-2184. https://doi.org/10.3168/jds.2009-2453.

Park, R. S., R. E. Agnew, F. J. Gordon, and R. W. J. Steen. 1998. The use of near infrared reflectance spectroscopy (NIRS) on undried samples of grass silage to predict chemical composition and digestibility parameters. Anim. Feed Sci. Technol. 72:155-167. https:// doi.org/10.1016/S0377-8401(97)00175-2.

Philipsson, J., and B. Lindhe. 2003. Experiences of including reproduction and health traits in Scandinavian dairy cattle breeding programmes. Livest. Prod. Sci. 83:99-112. https://doi.org/10.1016/ S0301-6226(03)00047-2.

Piccardi, M., D. Pipino, G. A. Bó, and M. Balzarini. 2014. Productive and reproductive performance of first lactation purebred Holstein versus Swedish red \& white $\mathrm{x}$ Holstein in central Argentina. Livest. Sci. 165:37-41. https://doi.org/10.1016/j.livsci.2014.04.025.

Pires, J. A. A., Y. Chilliard, C. Delavaud, J. Rouel, D. Pomies, and F. Blanc. 2015. Physiological adaptations and ovarian cyclicity of Holstein and Montbéliarde cows under two low-input production systems. Animal 9:1986-1995. https://doi.org/10.1017/ S1751731115001317.

Prendiville, R., E. Lewis, K. M. Pierce, and F. Buckley. 2010a. Comparative grazing behaviour of lactating Holstein-Friesian, Jersey, and Jersey $\times$ Holstein-Friesian dairy cows and its association with intake capacity and production efficiency. J. Dairy Sci. 93:764-774. https://doi.org/10.3168/jds.2009-2659.

Prendiville, R., K. M. Pierce, and F. Buckley. 2009. An evaluation of production efficiencies among lactating Holstein-Friesian, Jersey, and Jersey $\times$ Holstein-Friesian cows at pasture. J. Dairy Sci. 92:6176-6185. https://doi.org/10.3168/jds.2009-2292.

Prendiville, R., K. M. Pierce, and F. Buckley. 2010b. A comparison between Holstein-Friesian and Jersey dairy cows and their F1 cross with regard to milk yield, somatic cell score, mastitis, and milking characteristics under grazing conditions. J. Dairy Sci. 93:27412750. https://doi.org/10.3168/jds.2009-2791.

Purcell, P. J., A. J. Dale, A. W. Gordon, J. Barley, and C. P. Ferris. 2016a. Effects of predicted milk yields sustained by grazed grass on dairy cow performance and concentrate requirements throughout the grazing season. Grass Forage Sci. 71:389-402. https://doi.org/ $10.1111 /$ gfs. 12193.

Purcell, P. J., R. A. Law, A. W. Gordon, S. A. McGettrick, and C. P. Ferris. 2016b. Effect of concentrate feeding method on the performance of dairy cows in early to mid lactation. J. Dairy Sci. 99:2811-2824. https://doi.org/10.3168/jds.2015-9988.

Rastani, R. R., S. M. Andrew, S. A. Zinn, and C. J. Sniffen. 2001. Body composition and estimated tissue energy balance in Jersey and Holstein cows during early lactation. J. Dairy Sci. 84:12011209. https://doi.org/10.3168/jds.S0022-0302(01)74581-X.

Schmidt, E., and F. W. Schmidt. 1995. Glutamate dehydrogenase (EC 1.4.1.3). In Methods of Enzymatic Analysis. Vol. 3. 3rd ed. H. U. Bergmeyer, ed. Weinheim, Germany.

Sørensen, M. K., E. Norberg, J. Pedersen, and L. G. Christensen. 2008. Crossbreeding in dairy cattle: A Danish perspective. J. Dairy Sci. 91:4116-4128. https://doi.org/10.3168/jds.2008-1273.

Vance, E. R., C. P. Ferris, C. T. Elliott, H. M. Hartley, and D. J. Kilpatrick. 2013. Comparison of the performance of Holstein-Friesian and Jersey x Holstein-Friesian crossbred dairy cows within three contrasting grassland-based systems of milk production. Livest. Sci. 151:66-79. https://doi.org/10.1016/j.livsci.2012.10.011. 
Vance, E. R., C. P. Ferris, C. T. Elliott, and D. J. Kilpatrick. 2012b. A comparison of the feeding and grazing behaviour of primiparous Holstein-Friesian and Jersey x Holstein-Friesian dairy cows. Ir. J. Agric. Food Res. 51:45-61.

Vance, E. R., C. P. Ferris, C. T. Elliott, S. A. McGettrick, and D. J. Kilpatrick. 2012a. Food intake, milk production, and tissue changes of Holstein-Friesian and Jersey $\times$ Holstein-Friesian dairy cows within a medium-input grazing system and a high-input confinement system. J. Dairy Sci. 95:1527-1544. https://doi.org/10.3168/ jds.2011-4410.

VanRaden, P. M., and A. H. Sanders. 2003. Economic merit of crossbred and purebred US dairy cattle. J. Dairy Sci. 86:1036-1044. https://doi.org/10.3168/jds.S0022-0302(03)73687-X.

Walsh, S., F. Buckley, K. Pierce, N. Byrne, J. Patton, and P. Dillon. 2008. Effects of breed and feeding system on milk production, body weight, body condition score, reproductive performance, and postpartum ovarian function. J. Dairy Sci. 91:4401-4413. https:// doi.org/10.3168/jds.2007-0818.

White, S. L., J. A. Bertrand, M. R. Wade, S. P. Washburn, J. T Green, and T. C. Jenkins. 2001. Comparison of fatty acid content of milk from Jersey and Holstein cows consuming pasture or a total mixed ration. J. Dairy Sci. 84:2295-2301. https://doi.org/10 .3168/jds.S0022-0302(01)74676-0.

Wiking, L., T. Larsen, and J. Sehested. 2008. Transfer of dietary zinc and fat to milk-Evaluation of milk fat quality, milk fat precursors, and mastitis indicators. J. Dairy Sci. 91:1544-1551. https://doi .org/10.3168/jds.2007-0716. 